\title{
Rethinking Urban Poverty Alleviation Policies in Indonesia
}

\author{
Marita Ahdiyana ${ }^{1}$, Hardian Wahyu Widianto ${ }^{2}$, Argo Pambudi ${ }^{3}$ \\ ${ }^{123}$ Departemen of Public Administration, Universitas Negeri Yogyakarta \\ marita_ahdiyana@uny.ac.id ${ }^{1}$, hardianwahyuwidianto@uny.ac.id ${ }^{2}$,argo_pambudi@uny.ac.id ${ }^{3}$
}

\begin{abstract}
Worldbank stated that Indonesia is one of the cities with the highest number of poor people, on the same level as China and the Philippines. There is no specific study on the relationship between urban poverty alleviation policies and urban poverty in Indonesia. This paper aims to fill this gap using literature review methods. This study found that urban poverty alleviation programs only initiated after the 1997/1998 Asian financial crisis hit Indonesia. The ongoing poverty eradication efforts rely on social assistance schemes and community empowerment. The success or failure of various kinds of programs in this area relates to various other factors or policies that significantly affect the level of poverty starting from political conditions, domestic and global economic conditions, as well as various other domestic policies. The implication is that poverty alleviation efforts need to prioritize intervention in macroeconomic conditions, rather than developing various poverty alleviation programs.
\end{abstract}

Keywords: Urban, Poverty, Poverty Alleviation, Policy

\section{Introduction}

In 2019 poverty in Indonesia is at the lowest level in history, which is $9.41 \%$ or 25.14 million people. For the cabinet government of Joko Widodo (Jokowi) and Jusuf Kalla, of course, this achievement is considered as a proud achievement of the government's work[1]. However, success in poverty alleviation can not only measured by the percentage of poverty. The depth of poverty is another indication of poverty conditions. In March 2019, National Statistics Bureau recorded the poverty depth index of 1.55 (or 1.67 in 5 years from 20152019). This figure exceeds the achievement in the previous period 2010-2014, namely 1.40 . Inequality is another marker that is effective in completing the picture of poverty in Indonesia. The results of the Social Inequality Index Survey conducted by the International NGO Forum on Indonesian Development (INFID) show that inequality in Indonesia reached a score of 6 in 2018, an increase of 0.4 from 2017. The score of 6 shows that there are 6 out of 10 aspects of life that are unequal in Indonesia[2].

Although the distribution of poverty is more in rural areas (13.1\%), urban poverty $(6.89 \%)$ is not a trivial problem. Worldbank stated that Indonesia is one of the cities with the highest number of poor people, on the same level as China and the Philippines[3]. The issue of urban poverty is increasingly important, given the high rate of urbanization in Indonesia. Worldbank data records that the rate of urbanization in Indonesia reaches 3\% per year, while in 2019, the number of people living in urban areas has reached $55.8 \%$ of the population (around 150.9 million). Projections made by Worldometer estimate that within five years, the population in urban areas reach 170.4 million people or $59.3 \%$ of the population[4]. The denser cities are $\mathrm{k}$ to increase the level of poverty because the economic opportunities faced by newcomers are 
increasingly limited. Efforts to reduce poverty in urban areas also appear to be more difficult when compared to rural areas known. Suppose in one year the number of poor people in rural areas can significantly reduce from 15.81 million in 2018 to 15.15 million in 2019. In that case, the same condition does not occur in urban areas (from 10.14 million to 9.99 million only). These three reasons place urban poverty as a problem that cannot be ruled out in the poverty alleviation agenda[5]

Meanwhile, the cost of poverty alleviation programs in Indonesia has increased by up to $10 \%$ per year since 2015. In 2015 this budget was in only around IDR 140 trillion, while in 2019 it jumped quite sharply to IDR 200.8 trillion. Unresolved poverty problems to have triggered the emergence of a variety of other more severe social problems. Such as the emergence of child prostitution[2], unequal population growth, violence and crime[6], and in a severe degree it will trigger mass unrest such as in the crisis experience in 1998[7]. The existing studies are still limited to analyzing poverty alleviation policies in Indonesia in general: urban and rural areas[7]-[12]. There is no specific study on the relationship between urban poverty alleviation policies and urban poverty. This paper aims to fill this gap by understanding the various existing urban poverty alleviation policy schemes and the various factors that influence the success or failure of these policies.

\section{Method}

This research uses a literature study method. A literature study is the best method to synthesize the findings of previous studies. The purpose of conducting a literature study is not only to read the literature but more to the direction of an in-depth and critical evaluation of previous studies[13]. The data used in this study consisted of Journal articles, Proceedings, books and other scientific papers that analyze poverty alleviation in Indonesia in Bahasa or English; Poverty alleviation policies and programs; and various statistics related to poverty.

\section{Result And Discussion}

\subsection{Urban Poverty}

Pioneering poverty researcher Robert Chamber said there was ambiguity in translating the use of the term poverty. The meaning of poverty will very much depend on the tradition of the disciplines used, perspectives and ideology[14]. Historically, poverty will be closely related to income, which, until now, is still the core of the poverty concept. In the 19th century, the meaning of poverty evolved to the need for subsistence (survival). In the following century, in addition to subsistence needs, poverty was then associated with a lack of availability of basic needs, which included: health services, sanitation and education. In developments in the late 20 th century, the growing aspects of the core of poverty included income, other resources, and social conditions. Poverty is defined in a narrow sense as a shortage of resources and products to ensure survival. Although poverty can, in a broad sense, include items or maybe called multidimensional. Chambers said that five dimensions are integrated into poverty, namely: poverty itself, powerlessness, vulnerability when faced with an emergency (state of emergency), dependency, and isolation (geographic and sociological)[15]. 
According to the type, poverty can be separate into several forms. First, absolute poverty, which is a condition when income is below the poverty line or is not sufficient to meet the food, clothing, housing health, and education needed to live and work. Second, relative poverty, the creation of a state of poverty due to the influence of development policies that have not reached the entire population, which $\mathrm{H}$ an effect on the creation of income inequality. Third, cultural poverty is a condition of poverty that cause by the problem of a person's attitude or society. This poverty condition emerging because cultural factors, such as not wanting to try to improve the level of life, being lazy, wasteful, not being creative even though there is help from outside. Fourth, structural poverty, a miserable unfortunate situation that is born due to limited access to resources that occurs in a socio-cultural and political system that does not support poverty alleviation, instead it nourishes poverty[16].

The debate on the concept of urban poverty stems from a growing literature that focuses on the inequality between rural poverty and a better life in cities and,c urbanization. In developed countries, poverty analysis focuses more on problems that arise in inner-cities, or with unemployment and regional income inequality; and sectoral. The focus of the analysis is not unfamiliar with the inequality in rural and urban areas. In the colonial era, poverty in urban developing countries $\mathrm{c}$ through urbanization and the process of transferring workers from the agricultural sector with low productivity to advanced industries with high productivity[17].

\subsection{Development Urban Poverty Reduction Policies Scheme in Indonesia}

As a new government faced with severe economic conditions, the Soekarno government attempted to increase national economic independence. In his dreamed economic program, Soekarno formed a National Planning Council which was assigned to compile Pembangunan Nasional Berencana Delapan tahun (Penasbede)/ the Eight-Year Universal Development Plan (Panasbede). This plan based on three main principles. Regulation and coordination by the state of all economic activities (state, private and cooperative) to ensure adequate production and distribution of national economic development; controlling foreign capital to fulfil national development goals; and replacing the colonial, export-oriented economy with an independent, industrialized domestic economy[18]. In terms of social assistance programs, President Soekarno specifically created a Program Sandang Pangan /Food and Clothing program to provide clothing and food for the community.

The poverty reduction strategy in the Suharto era was not through poverty alleviation policies but relied on pro-poor development policies and programs. Pro-poor is a term used for primarily national policies to stimulate economic growth for the benefits of poor people (primarily in the economic sense of poverty). Meanwhile, poverty alleviation programs are given directly to the poor[19]. Therefore, pro-poor policies resolve poverty through programs that do not specifically target the poor. The government seeks to increase growth by building infrastructure, agricultural development (green revolution), developing small businesses, various construction projects and setting minimum wage policies. Besides, other programs that are closer to the needs of the poor, such as the provision of primary basic education and health facilities, the development of roads and communication networks, and the provision of clean water[20]. In 1994 government introduced the first specific poverty alleviation policy, under the name Inpres Desa Tertinggal (IDT)/ Disadvantaged Village Presidential Instruction. IDT can seen as the only poverty alleviation program during the Soeharto era. Until the end of Soeharto's government, there was no poverty alleviation program in cities specifically[19].

The 1997 economic crisis, which resulted in a decrease in the income of most of the poor and increased the prices of basic needs, has created a complicated problem for Indonesia. 
During this historical period, President Soeharto de to place his office. President Habibi, who later replaced Suharto, accompanied by donor agencies, prepared a Social Safety Net program package to reduce the impact of increasingly severe poverty. Two times changing presidents (A. Wahid and Megawati), the poverty alleviation program has not changed significantly. The social safety net not a single program, utterly new program, but a combination of various previous programs in various ministries that are less effective and coordinated and added with several new programs. Itis planned that this program would cost up to IDR 17 trillion, which comes from donor assistance, including in a controversial loan from the World Bank, better known as the Social Safety Net Adjustment Loan [21].

This program package implements through interventions on four basic needs. First, in terms of employment, the government provided an emergency job creation scheme to assist those who lost their jobs in the formal sector as a result of the crisis. However, there is no specific program, but instead, various programs before and during the crisis that had the same attributes as labour-intensive programs (Perdana \& Maxwell, 2005;101-102). Second, in the field of food safety, special food assistance program has been designed to maintain the availability of medium quality rice every month to the poor and needy families at low prices. This program became known as Operasi Pasar Khusus (OPK)/ Special Market Operation, which provided $10 \mathrm{~kg}$ of rice to $\mathrm{n}$ families at $1000 / \mathrm{kg}$. In 2002 , this program changed its name to Beras Untuk Rumah Tangga Miskin (Raskin) / Rice for the poor Household[22].

Third, in the education sector, the government has provided a scholarship and Dana Bantuan Operasional (DBO)/ grant assistance program. This program provides special assistance to students from low-income families and certain schools, to prevent an increase in dropout rates due to a decrease in the income of both parents and an increase in the cost of education. The scholarship program is necessary to keep children in school by offering cash support to students in order to improve their chances of attending education to the next level. Meanwhile, the Grants program aims to help schools maintain the quality of their programs in the face of increasing costs for school supplies and other essential equipment. In 2001, to support this program, a Special Assistance for Students and Special The Special Assistance for Students and the Special Assistance for Schools assistance program was provided, which received support from the transfer of fuel subsidies[20].[20]. Fourth, in the health sector, the government has made a program with the broadest coverage to ensure access to public health services for the poor, sure, the Health Sector Social Safety Net / JPS-K). At the cost of up to IDR 1.4 trillion, this policy package provides the following programs: Improving nutritional standards through the provision of supportive food for infants, children, malnourished communities and pregnant women; Support for midwife services; Support for Puskesmas and; Provide a Community Health Care Guarantee program (Public Health Insurance, JPKM), financed by a district-level committee[20]. JPS-K replace by the Program Kompensasi Pengurangan Subsidi (PKPS-BBM)/ Fuel Subsidy Reduction Compensation Program after receiving compensation for the increase in fuel prices.

Apart from Social Safety Nets, assistance from donors during the crisis also took the form of a community empowerment program, specifically for urban areas called the Program Pengentasan Kemiskinan Perkotaan (P2KP)/ Urban Poverty Alleviation Program. This program aims to empower the community to accelerate efforts to reduce poverty in urban areas. This program provides rotating capital within the community to generate sustainable income for the urban poor and groups. Apart from that, the program also provides financing for the basic infrastructure of choice for the community and job creation activities in poor urban areas. This program initially targeted the poor in 60 areas of northern Java's 
government, mainly Yogyakarta, Malang and Bandung, which consisted of dense cities with small industries [22].

The social security program during the previous administration still was continued during the president Susilo Bambang Yudhoyono (SBY) administration despite changes. In the health sector, although it still uses funding sources from the reduction of fuel subsidies, the PKSPBBM program in the early days of the SBY administration (2005-2008) has changed its name to Asuransi Kesehatan Bagi Keluarga Miskin (Askeskin)/ Health Insurance for Poor Families. Due to the less than optimal managerial performance of Askeskin, this scheme converted to Jaminan Kesehatan bagi Masyarakat Miskin (Jamkesmas)/ Health Insurance for the Poor. The fundamental difference in the new scheme lies in individual participation [22]. In order to reduce the potential negative impact of lowering fuel subsidies for the poor, in 2005 the SBY government introduced a new program with the cash transfer approach, namely Bantuan Langsung Tunai (BLT)/ Direct Cash Assistance. This programme aimed to increase the financial liquidity of poor households by providing funds of Rp 100,000 per month, sourced from the reduction in fuel subsidies. The BLT program only ran until 2009 and was replaced by the conditional cash transfer program, Program Keluarga Harapan (PKH)/ Hopeful Family Program. Through PKH, households will receive the assistance of IDR 600,0002,200,000 per year, depending on education and health prerequisites. PKH directed to help indigent households[22]

Apart from BLT, the most monumental urban poverty reduction program in the SBY era was Program Nasional Pemberdayaan Masyarakat (PNMP Mandiri)/ National Community Empowerment Program. PNPM originated from a pattern of poverty alleviation that to be partial, so it did not work effectively. Therefore, at the end of 2006, various poverty reduction programs were integrated under the PNMP Mandiri umbrella. The primary main source of PNPM funding comes from the program budgets of each ministry that is part of this umbrella, as well as Anggaran Penerimaan dan Belanja Daerah (APBD)/ Regional Revenue and Expenditure Budget. PNPM funds only finance the implementation of the program by 20-50 per cent of the funds required, while the rest are being brought up from sponsors, both grants and loans[22]. As a program that effective in reducing poverty in urban areas, creating jobs and increasing participation, P2KP will continue and be merged into the core program of PNMP-Mandiri. More fully, the activities in this program include community development, direct community assistance, increasing government capacity to facilitate the community and assistance in program management and development [8].

During the Jokowi administration, there were not many poverty alleviation programs that were new. Several programs are continuing the legacy of the program during SBY's term with certain changes. In the education sector, Bantuan Operasional Sekolah (BOS) / School Operational Assistance program is still co with an increase in the budget from Rp. 47.4 trillion to Rp. 65.7 trillion. PKH is also continuing with modifications in the form of local government involvement, doubling the coverage of participants (3.2 to 6.4 million indigent households), changing the range of assistance also changing from 1.3-2.8 million to 0,9-3.7 million / household/year, and the budget increased from Rp. 4.4 trillion to Rp. 6.4 trillion.PNPM, which underlies the P2KP, is also still being maintained, but with fairly high budget preparation of Rp. 11.1 trillion[23].

Several other programs with new names were programs that also existed in the SBY era but underwent a name change. The Poor Student Assistance Program (BSM) changed its name to Kartu Indonesia Pintar (KIP)/ Smart Indonesia Card, with modifications to the addition of target recipients from 11.2 million poor students to 20.3 million, and an increase in the budget from Rp. 9.1 trillion to Rp. 15.5 trillion. Jaminan Kesehatan Nasional (JKN)/ National Health 
Insurance Program changed its name to the Healthy Indonesia Card (KIS) with an increase in the budget of Rp. 2.9 trillion. The Raskin also changed its name to Beras Sejahtera (Rastra)/ Prosperous Rice with an additional budget of Rp. 0.7 trillion. Bantuan Langsung Tunai (BLT)/ cash direct assistance program and Bantuan Lansgung Sementara Masyarakat (BLSM) / temporary direct assistance for the community also changed its name to the Program Simpanan Keluarga Sejahtera (PSKS) welfare family savings program. This program had change use cash but through a savings account, and there is an additional budget of Rp. 6.4 trillion to IDR 10.1 trillion[23].

\subsection{Influencing Factors and their Impacts}

At a very young age, the Indonesian state has borne a high economic burden. The Soekarno government forced to pay a debt for the costs of the Dutch government's war against Indonesia amounting to 4.3 million guilders. The condition of the domestic economy is still not stable. This condition can be seen from the state companies are only able to operate in a limited manner because; limited capital, minimal maintenance costs for machines, limited foreign exchange reserves for importing technology and raw materials, management incompetence and corruption in companies, and the shrinking number of skilled workers and Dutch experts. This situation exacerbated by the problem of food crisis in Java, 1962- 1966, due to a lack of irrigation network development. As a result, foreign exchange reserves are dwindling, because the government needs to import more than 1 million tonnes of food every year. As a result, the Program Sandang Pangan/ Food and Clothing program failed to e implemented. Various economic problems have made the city community begin to oppose the government because they are considered incompetent in managing the economy[18]. This problematic condition became increasingly tense when the September 30, 1965 incident occurred. Economic problems were then neglected because all public attention as focused on this event which claims cut down hundreds of thousands of people. It is difficult to find exact data on poverty in the 1959-1967 period. However, at least the decline in per capita income of $1.6 \%$ per year from 1960-1967 represents a condition of increasingly severe poverty[24]. The per capita income of the Indonesian people even only reached half of the people in India at that time. As a result, Soekarno was often seen as having left a terrible economic condition.

Starting from this extreme situation, Suharto, who later took power and was able to eradicate poverty throughout his 32 years of rule, indeed certainly became the centre of global attention. The poverty rate in cities at the beginning of the government was quite high, reaching $38.8 \%$, and was drastically reduced to the remaining $9.7 \%$ before the economic crisis hit. However, as previously explained, this reduction did not come from poverty alleviation programs but a pro-poor growth strategy. Soeharto and his economists believed that economic growth would be able to help reduce poverty.

Three primary ain sources made urban poverty in Soeharto a significant reduction. First, related to economic rehabilitation efforts (exchange rate balancing, control of rice prices), infrastructure development using foreign assistance (as well as oil revenues), and trade and investment liberalization [25]. Second, the rapid growth of agricultural productivity due to the adoption of new technologies and massive investment in rural infrastructure. The success of development in agriculture has effectively reduced urbanization because the productivity gap in rural and urban areas is not too wide. As a result, not many workers have the potential to increase poverty by migrating to cities. Third, direct investment and exports have triggered the emergence of a manufacturing industry that absorbs a lot of labour [25]. The success of 
development in the various fields mentioned above basically cannot be separated from two crucial factors, namely, oil revenues and foreign investment.

The results of poverty alleviation in the Suharto era must end when the Asian financial crisis in 1997/1998 was unavoidable for Indonesia. Habibi is faced with Soeharto's legacy in the form of a rupiah exchange rate of up to $85 \%$, the economy contracting up to $13.7 \%$, flying food prices up to $118 \%$, and inflation has touched $78 \%[9]$. The poverty rate in urban areas has risen sharply from the original $9.7 \%$ to $21.9 \%$. Assistance from donor agencies is the main lifesaver for the Habibi government to deal with this high level of poverty. Assistance can affect poverty indirectly (increasing economic growth that benefits the poor and provides basic needs) and directly (distributed to the poor either in cash or in financing poverty alleviation programs)[26]. After the crisis, donors assisted Indonesia to establish a particular ministry responsible for designing and implementing poverty alleviation policies, namely, Kementrian Koordinator Kesejahteraan Rakyat (Menkokesra)/ Coordinating Ministry for People's Welfare.

However, post-crisis poverty reduction is no longer as rapid as it was before the crisis. The Habibi government had reduced urban poverty from $21.9 \%$ to $19.5 \%$. In A. Wahid's hands, poverty again increased from $9.76 \%$ to $14.46 \%$, and gradually decreased again to reach $12.13 \%$ at the end of Megawati's administration. A. Wahid's government was quite problematic because the political elite opposed his various policies. When changing to Megawati, poverty did decline but experienced a slowdown. The low post-crisis economic growth is considered to be the cause of the slow reduction in poverty. The post-crisis economy relies more on the service sector to replace the manufacturing industry that was unable to absorb more workers than before the crisis[9].

Many observers know the era of SBY's government as Indonesia's decade of stability and stagnation. Initially, the SBY government faced a vulnerable economic condition because it had just emerged from the 1997/98 Asian financial crisis, while in mid-government, it was again faced with the threat of the 2008 global crisis. However, during the two decades of its administration, the urban poverty rate decreased from $12.3 \%$ to $8.6 \%$. Despite having various kinds of social policies to alleviate poverty, SBY these various programs are considered to represent his choice of playing it safe. He avoided setting clear targets and indicators of the program and still did not have a clear vision in facing future challenges. Besides, a number of these programs tend to have poor design and short-term thinking[27]

SBY's success in maintaining economic stability in order to safeguard poverty alleviation efforts is related to two economic principles. First, to boost economic growth, SBY carried out rehabilitation and maintained macroeconomic stability. Second, its precautionary nature has made it delay or not even answer to the various challenges of severe economic policies that have arisen. Such as opportunities for subsidy reform that have not been maximized. Both of these strategies have succeeded in keeping the economy stable, but the side effect of stagnation is a logical consequence that must be accepted. Although the "spirit" of poverty eradication was felt during SBY's leadership, the inequality rate continued to experience a sharp increase [28].

Various kinds of reforms to poverty alleviation policies carried out in the Jokowi administration succeeded in reducing the poverty rate in urban areas from $8.16 \%$ in 2014 to $6.56 \%$ in 2019 . This decrease is related to the rapid development of funding for poverty alleviation programs that come from cutting fuel-subsidy. Therefore, fuel subsidy reform has become the most crucial policy in Jokowi's administration because it can to produce quite visible effects from a programmatic and physical perspective. The government was able to increase infrastructure spending up to $70 \%$ in the 2015 state budget as a result of this reform. 
Apart from that, reforms also supported by the existence of a package of economic policies aimed at boosting economic activity. This package of policies facilitates the market by cutting bureaucratic procedures, helping the industry import raw materials and incentivizing exports, reducing financial security, and making minimum wage determination more predictable[23].

Table 1. Classification of Poverty Alleviation Programs and Influencing Factors.

\begin{tabular}{|c|c|c|c|c|c|}
\hline \multirow{2}{*}{$\begin{array}{c}\text { Program } \\
\text { Classification }\end{array}$} & \multicolumn{5}{|c|}{ Regime } \\
\hline & $\begin{array}{c}\text { Soekarno } \\
(1945-1965)\end{array}$ & $\begin{array}{c}\text { Soeharto (1965- } \\
\text { 1998) }\end{array}$ & $\begin{array}{l}\text { B.J.Habibi, A. } \\
\text { Wahid, and } \\
\text { Megawati } \\
(1999-2000)\end{array}$ & $\begin{array}{l}\text { Yudhoyono } \\
(2005-2014)\end{array}$ & $\begin{array}{c}\text { Jokowi } \\
(2015- \\
2019)\end{array}$ \\
\hline \multicolumn{6}{|c|}{ Social Assistance } \\
\hline Food Security & $\begin{array}{l}\text { Program } \\
\text { Sandang } \\
\text { Pangan }\end{array}$ & & $O P K$ & Raskin & Rastra \\
\hline \multirow[t]{2}{*}{ Education } & & & $\begin{array}{l}\text { JPS- } \\
\text { Scholarship }\end{array}$ & $B S M$ & KIP \\
\hline & & & $\begin{array}{l}\text { Dana Bantuan } \\
\text { Operasional }\end{array}$ & $B O S$ & $B O S$ \\
\hline Health & & & $J P S-K$ & $J K N$ & KIS \\
\hline $\begin{array}{l}\text { Unconditional } \\
\text { Cash Transfer }\end{array}$ & & & & $B L T, B L S M$ & PSKS \\
\hline $\begin{array}{l}\text { Conditional } \\
\text { Cash Transfer }\end{array}$ & & & & PKH & PKH \\
\hline \multicolumn{6}{|c|}{ Empowerment and Labour Intensive Program } \\
\hline \multirow[t]{2}{*}{$\begin{array}{l}\text { Empowerment } \\
\text { \& Labour } \\
\text { Intensif }\end{array}$} & & & $\begin{array}{l}\text { JPS-Padat } \\
\text { Karya }\end{array}$ & & \\
\hline & & & P2KP & $\begin{array}{l}\text { PNPM- } \\
\text { P2KP }\end{array}$ & $\begin{array}{l}\text { PNPM- } \\
\text { P2KP }\end{array}$ \\
\hline \multicolumn{6}{|c|}{ Influencing factor and other poverty reduction approach } \\
\hline $\begin{array}{l}\text { Influencing } \\
\text { Factor }\end{array}$ & $\begin{array}{l}\text { Lack of } \\
\text { state fund, } \\
\text { Food Crises, } \\
\text { Political } \\
\text { Criss, }\end{array}$ & $\begin{array}{l}\text { Oil price and } \\
\text { Foreign } \\
\text { investment }\end{array}$ & $\begin{array}{l}\text { Asian Financial } \\
\text { Crisis and Aid } \\
\text { from donor }\end{array}$ & $\begin{array}{l}\text { Global } \\
\text { Crises } 2008 \text {, } \\
\text { SBY } \\
\text { Economy } \\
\text { Principals }\end{array}$ & $\begin{array}{l}\text { Fuel } \\
\text { Subsidy } \\
\text { Reform. }\end{array}$ \\
\hline $\begin{array}{l}\text { Other Poverty } \\
\text { Reduction } \\
\text { approach }\end{array}$ & & $\begin{array}{l}\text { Pro-poor growth } \\
\text { development: } \\
\text { Economy } \\
\text { Rehabilitation, } \\
\text { Green Revolution, } \\
\text { and } \\
\text { Industrialization }\end{array}$ & & & \\
\hline
\end{tabular}

\section{Conclusion}

The poverty alleviation program in urban areas was only initiated after the Asian financial crisis hit Indonesia in 1997/1998. The ongoing poverty alleviation efforts rely on social assistance schemes and community empowerment. In the first scheme, the government seeks to meet basic needs including food security (OPK, Raskin, Rastra,), education (JPS Scholarship, BSM, KIP), health (JPS-K, JKN, KIS) and direct finance (BLT, BLSM , PSKS, $\mathrm{PKH}$ ) and indirect (provision of facilities; DBO, BOS, JPS-K). In the next scheme, the government seeks to empower the community to be able to fulfil their needs independently (P2KP \& PNPM) or to open a labour-intensive program that can employ people (JPS-Solid Karya). The success or failure of various kinds of programs in this area cannot be separated 
from various other factors or policies that significantly affect the poverty level. These factors range from political conditions (political crisis 1965), domestic economic conditions (lack of state income and food crisis), global (world oil prices, foreign investment, the 1997/1998 Asian financial crisis, donor assistance and the 2008 global crisis), to various domestic policies (pro-poor development strategies in the Suharto era, SBY's economic policies, and massive subsidy reform in the Jokowi era). The implication is that poverty alleviation efforts need to prioritize intervention in macroeconomic conditions, rather than developing various poverty alleviation programs.

\section{References}

[1] H. Friana, "Di Depan DPR, Jokowi Ungkap Kemiskinan Turun Tajam 5 Tahun Ini,” Tirto.id, Aug-2019.

[2] E. Valenta, "Survei INFID: Ketimpangan sosial di Indonesia masih tinggi," Lokadata.id, 23Sep-2018.

[3] H. Purnomo, "Bank Dunia Juga Bicara Kemiskinan di Perkotaan RI yang Tinggi," CNBCIndonesia, Jan-2019.

[4] D. H. Jayani, "Berapa Jumlah Penduduk Perkotaan di Indonesia?,” Databoks, 11-Sep-2019.

[5] Y. Pusparisa, "Jumlah Penduduk Miskin di Desa dan Kota Mengalami Penurunan," Databoks, 2019.

[6] A. N. Wahyuli, "Pengentasan Kemiskinan Menurut Al-Quran," UIN Sunan Ampel Surabaya, 2016.

[7] S. Dhanani and I. Islam, "Poverty, vulnerability and social protection in a period of crisis: The case of Indonesia," World Dev., vol. 30, no. 7, pp. 1211-1231, 2002, doi: 10.1016/S0305750X(02)00028-1.

[8] S. Royat, "Kebijakan pemerintah dalam penanggulangan kemiskinan,” no. 1, pp. 2005-2009, 2009.

[9] A. Suryahadi, G. Hadiwidjaja, and S. Sumarto, "Economic growth and poverty reduction in Indonesia before and after the Asian financial crisis," Bull. Indonesia. Econ. Stud., vol. 48, no. 2, pp. 209-227, 2012, doi: 10.1080/00074918.2012.694155.

[10] B. Hofman, E. Rodrick-Jones, and T. K. Wie, "Indonesia: Rapid Growth, Weak Institutions," World Bank Policy Res. Work. Pap., 2004.

[11] A. M. Balisacan, E. M. Pernia, and A. Asra, "Revisiting growth and poverty reduction in Indonesia: What do subnational data show?," Bull. Indonesia. Econ. Stud., vol. 39, no. 3, pp. 329-351, 2003, doi: 10.1080/0007491032000142782.

[12] K. Kis-Katos and R. Sparrow, "Poverty, labour markets and trade liberalization in Indonesia," $J$. Dev. Econ., vol. 117, pp. 94-106, 2015, doi: 10.1016/j.jdeveco.2015.07.005.

[13] A. Liberati et al., "The PRISMA statement for reporting systematic reviews and meta-analyses of studies that evaluate health care interventions: Explanation and elaboration," PLoS Med., vol. 6, no. 7, 2009, doi: 10.1371/journal.pmed.1000100.

[14] R. Chambers, "What is poverty? Who asks? Who answers?.," 2006.

[15] R. Chambers, "Poverty and livelihoods: Whose reality counts?," Environ. Urban., vol. 7, no. 1, pp. 173-204, 1995, doi: 10.1177/095624789500700106.

[16] C. Suryawati, "Memahami kemiskinan secara multidimensional," JMPK, vol. 08, no. 03, pp. 121-129, 2005.

[17] E. Wratten, "Conceptualizing urban poverty," Environ. Urban., vol. 7, no. 1, pp. 11-38, 1995, doi: 10.1177/095624789500700118.

[18] M. Habibi, Surplus Pekerja di Kapitalisme Pinggiran : Relasi Kelas, Akumulasi dan Proletariat informal di Indonesia sejak 1980aj. Tangerang: Marjin kiri, 2016.

[19] T. Tambunan, "Economic Growth, Appropriate Policies and Poverty Reduction in a Developing 
Country: Some Experience from Indonesia," South Asia Econ. J., vol. 6, no. 1, pp. 59-78, 2005, doi: $10.1177 / 139156140500600104$.

[20] A. A. Perdana and J. Maxwell, "Poverty Targeting in Indonesia," in Poverty Targeting in Asia, J. Weiss, Ed. Cheltenham - Northampton: Edward Elgar, 2005.

[21] M. Sumarto, "Welfare Regime Change in Developing Countries: Evidence from Indonesia," Soc. Policy Adm., vol. 51, no. 6, pp. 940-959, 2017, doi: 10.1111/spol.12340.

[22] A. Suryahadi, A. Yumna, U. R. Raya, and D. Marbun, "Review of Government's Poverty Reduction Strategies, Policies, and Programs in Indonesia," Res. Report, SMERU Res. Inst., no. October, pp. 1-43, 2010.

[23] A. A. Yusuf and A. Sumner, "Growth, Poverty and Inequality under Jokowi," Bull. Indones. Econ. Stud., vol. 51, no. 3, pp. 323-348, 2015, doi: 10.1080/00074918.2015.1110685.

[24] R. Grabowski, "Indonesian economic development: Political economy of an effective state," $J$. Asia Pacific Econ., vol. 16, no. 2, pp. 241-253, 2011, doi: 10.1080/13547860.2011.564748.

[25] C. P. Timmer, "The road to pro-poor growth : the Indonesian experience in regional perspective,” Bull. Indones. Econ. Stud., vol. 4918, 2010, doi: 10.1080/0007491042000205277.

[26] T. Tambunan, "Aid and Poverty Reduction: The Indonesian Experience," 2006.

[27] D. Wisnu, F. Basri, and G. A. Putra, "Ambitious but inadequate: social welfare policies under Yudhoyono," in The Yudhoyono Presidency: Indonesia's Decade of Stability and Stagnation, E. Aspinall, M. Mietzner, and D. Tomsa, Eds. Singapore: ISEAS, 2014.

[28] H. Hill, "The Indonesian economy during the Yudhoyono decade," in The Yudhoyono Presidency: Indonesia's Decade of Stability and Stagnation, E. Aspinall, M. Mietzner, and D. Tomsa, Eds. Singapore: ISEAS, 2014, pp. 281-302. 